\title{
Infratentorial superficial siderosis: classification, diagnostic criteria and rational investigation pathway
}

\section{Running title: superficial siderosis: diagnosis and investigation}

Duncan Wilson $\mathrm{MD}^{1^{*}}$, Fiona Chatterjee $\mathrm{MD}^{2^{*}}$, Simon F Farmer $\mathrm{PhD}^{3}$, Peter Rudge $\mathrm{FRCP}^{3}$, Mark O McCarron $\mathrm{MD}^{4}$, Peter Cowley $\mathrm{MD}^{2 \#}$, David J Werring $\mathrm{PhD}^{1 \#}+$

1 Stroke Research Centre, Department of Brain Repair and Rehabilitation, UCL Institute of Neurology Russell Square House, London, UK

2 Lysholm Department of Neuroradiology, National Hospital for Neurology and Neurosurgery, London, UK

3 National Hospital for Neurology and Neurosurgery, London, UK

4 Department of Neurology, Altnagelvin Hospital, Derry, UK

* Both authors contributed equally to the paper

\# Both authors contributed equally to the paper

† Corresponding author: David J. Werring, PhD, Professor of Clinical Neurology, Stroke Research Centre, Department of Brain Repair and Rehabilitation, First Floor, Russell Square House, 10-12 Russell Square, WC1N 5EE, United Kingdom. E-mail d.werring@ucl.ac.uk

Word count (abstract): 250

Word count (body): 3457

Figures: 7 ( 1 color, with grayscale version for print)

Tables: 1

Supplementary tables: 1 (very large)

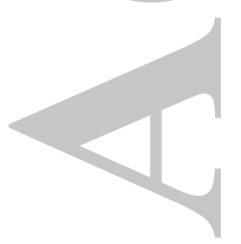

This article has been accepted for publication and undergone full peer review but has not been through the copyediting, typesetting, pagination and proofreading process which may lead to differences between this version and the Version of Record. Please cite this article as an 'Accepted Article', doi: 10.1002/ana.24850 


\section{Abstract}

Central nervous system infratentorial superficial siderosis (iSS) is increasingly detected by blood-sensitive MRI sequences. Despite this, there are no standardized diagnostic criteria, and the clinical-radiological spectrum, causes and optimum investigation strategy are not established. We reviewed clinical and radiological details of patients with iSS assessed at a specialist neurological center from 20042016 using pre-defined standardized radiological criteria. All imaging findings were rated blinded to clinical details. We identified 65 patients with iSS, which we classified into two groups: type 1 (classical) and type 2 (secondary) iSS. Type 1 (classical) iSS included 48 patients without any potentially causal radiologicallyconfirmed spontaneous or traumatic intracranial hemorrhage, of whom 39 (83\%) had hearing loss, ataxia or myelopathy; type 2 (secondary) iSS included 17 patients with a potentially causal radiologically-confirmed spontaneous or traumatic intracranial hemorrhage, of whom none had hearing loss, ataxia or myelopathy. Of the patients with type 1 (classical) iSS, $40(83 \%)$ had a potentially causal cranial or spinal dural abnormality; 5 (11\%) had an alternative cause; and $3(6 \%)$ had no cause identified. Intra-arterial digital subtraction angiography did not identify any underlying causal lesions for type 1 iSS. Type 1 (classical) iSS, defined using simple radiological criteria, is associated with a characteristic neurological syndrome. Rational investigation, including spinal MRI, nearly always reveals a potential cause, most often a dural abnormality. Catheter angiography appears to be unhelpful, suggesting that classical iSS is not associated with macrovascular arterial pathology. Recognition of type 1 (classical) iSS should allow timely diagnosis and early consideration of treatment. 


\section{Introduction}

Superficial siderosis of the central nervous system is considered to be a rare condition resulting from hemosiderin deposition in the subpial layers of the brain, cranial nerves and spinal cord. ${ }^{1}$ It was first described in $1908^{2}$ and is hypothesized to result from an insidious, low volume but protracted or repetitive 'leak' of red blood cells into the subarachnoid space. ${ }^{3}$ In response to the resultant neurotoxic heme, Bergmann glia and microglia release hemoxygenase- 1 and ferritin. Hemoxygenase-1 breaks down heme into free iron and biliverdin, while ferritin binds free iron to produce hemosiderin, a stable breakdown and product likely cause of radiologically detected superficial siderosis. Continuous subarachnoid leakage is hypothesized to eventually overwhelm ferritin synthesis, leading to the neuronal accumulation of neurotoxic iron and light chain ferritin (Fig 1), often with a very long latency (sometimes decades) between the presumed origin of the leak and the development of the clinical and radiological syndrome. The posterior fossa is most affected by siderotic deposition due to the abundance and close proximity of microglia and Bergmann glia in the cerebellum ${ }^{4}$ and vestibulocochlear nerve. ${ }^{5}$ The cerebellar convexities and superior cerebellar vermis are particularly affected, often with associated atrophy, probably because of the pattern of CSF flow; the cerebellar convexities and flocculus are irrigated earliest ${ }^{6}$ and are continuously exposed to hemorrhagic cerebrospinal fluid (CSF). ${ }^{7}$ The olfactory and vestibulocochlear cranial nerves are also especially vulnerable: the olfactory nerve is a central nervous system (CNS) structure, while the eighth cranial nerve, in contrast to other "true" cranial nerves, has a glia limitans which is nearly 10 mm from the medulla ${ }^{8,9}$.

Until the advent of MRI, superficial siderosis of the CNS could only be inferred in life from clinical findings and CSF studies, with diagnostic confirmation only possible post mortem ${ }^{10}$. With the increasing use of MRI, including blood-sensitive sequences, "superficial siderosis" is now a common radiological diagnosis. Two anatomical patterns of superficial siderosis are increasingly recognized: (1) cortical superficial siderosis (cSS) restricted to the supratentorial cerebral convexities, which (in older individuals) is often associated with cerebral amyloid angiopathy ${ }^{11,12}$ and transient focal neurological episodes ${ }^{13}$; and (2) infratentorial superficial siderosis 
(iSS), (with or without supratentorial involvement), which typically presents with slowly progressive hearing loss, ataxia and myelopathy ${ }^{1,9}$. A wide range of suggested causes of iSS ${ }^{9}$ include subarachnoid hemorrhage from intracranial aneurysms, arteriovenous malformations, tumors, cerebral amyloid angiopathy, and spinal epidural CSF collections ${ }^{14-19}$. Investigations used include MRI of the brain and spine; intra-arterial digital subtraction angiography of the brain or spine; CT myelography; ${ }^{20}$ and surgical exploration ${ }^{17}$. While diagnostic criteria and investigation pathways for cSS have recently been suggested, ${ }^{21}$ we are not aware of such criteria or pathways for iSS. There thus remains uncertainty regarding how to define, classify or investigate iSS.

We therefore reviewed all cases of superficial siderosis assessed at our specialist neurological centre, aiming to: (1) describe the clinical and radiological spectrum and causes of iSS, using pre-defined standardized radiological criteria for iSS; and (2) develop a rational investigation algorithm.

\section{Patients and Methods}

We prospectively included all patients with suspected iSS referred for assessment to the National Hospital for Neurology and Neurosurgery, Queen Square, London (a tertiary neurology centre), from 20/09/2013, as well as those identified by a retrospective keyword search of radiological reports for the term "superficial siderosis" between 30/06/2004 and 30/01/2014. Two consultant neuroradiologists (FC and PC), and a consultant vascular neurologist (DJW) reviewed all available imaging, blinded to all patient details. Infratentorial superficial siderosis was defined according to pre-specified standardized radiological criteria based upon many years of author experience of reviewing imaging of patients with the typical syndrome of superficial siderosis of the CNS and internal author consensus: bilateral (symmetrical) welldefined curvilinear homogeneous low signal on T2 or blood-sensitive sequences (T2* gradient echo or susceptibility-weighted imaging) over the superficial surface of at least two of the following regions: (1) brainstem (including midbrain, pons, medulla); (2) cerebellum (including the cerebellar folia, vermis, and cerebellar peduncles); and (3) spinal cord or cranio-cervical junction. The additional presence of supratentorial siderosis was not an exclusion criterion. In each patient the presumed epicentre and 
distribution (both infratentorially and supratentorially) of siderosis was noted, and the severity of siderotic deposition was visually graded as mild (a slender rim on but visible on T2), moderate or severe (an obvious thick rim seen on T2). Associated intracerebral hemorrhage was classified as lobar or deep (including the basal ganglia, brainstem or cerebellum) depending on the presumed epicentre of the hemorrhage.

All authors reviewed the clinical features (from all available medical records and with additional personal clinical evaluation by DJW, DW, MM or SF). We recorded the presence of the typical clinical features of "classical" iSS for each patient (we prespecified these as hearing loss, ataxia, or myelopathy, but also noted other neurological abnormalities e.g. anosmia, sphincter dysfunction, etc.). We documented radiological features and all other investigations (e.g. CSF analysis). We determined the presumed cause of iSS by consensus among all authors, based upon all available clinical and radiological information.

The project involved only routinely collected clinical data, and was approved as a clinical service evaluation by the Clinical Governance department of the National Hospital for Neurology and Neurosurgery, University College Hospitals NHS Foundation Trust, and was judged not to require formal ethical committee approval.

\section{Results}

\section{Identification of patients}

We identified 65 patients with iSS: 31 from a prospective consecutive registry of referrals to our service; and 34 from a retrospective radiological search (Fig 2) (Table 1). The radiology keyword search initially yielded 111 unique patients with definite superficial siderosis, of whom 77 were excluded (54 with only supratentorial siderosis (causes shown in Table 1), and 23 with restricted infratentorial siderosis not fulfilling our pre-defined radiological criteria), providing a final total of 34 patients with iSS. None of the patients identified from this search with either isolated supratentorial siderosis $(\mathrm{n}=54)$ or restricted infratentorial siderosis $(\mathrm{n}=23)$ had any of the pre-defined "classical" clinical features of superficial siderosis of the CNS (hearing loss, ataxia, or myelopathy) (Table 1). 


\section{Clinical and radiological features of infratentorial superficial siderosis}

The median age of the 65 patients with iSS defined according to our standardized criteria was 56 (range, 44-65); 47 (72\%) were male. We identified two distinct groups, classified by their presumed mechanism, which we term: Type 1 (classical) iSS and Type 2 (secondary) iSS. Type 1 (classical) iSS occurs where there is no obvious spontaneous or traumatic intracranial hemorrhage that could account for the observed pattern of siderosis. Type 2 (secondary) iSS occurs where there is an obvious single spontaneous or traumatic intracranial hemorrhage that, based on its spatial distribution and timing, was thought to be the likely cause of the observed pattern of siderosis.

\section{Type 1 (classical) infratentorial superficial siderosis}

In 48 patients had Type 1 (classical) iSS. 40 (83\%) of these patients had at least one of the three typical clinical features of "classical" superficial siderosis of the CNS (hearing loss 31/40 (78\%), ataxia 31/40 (78\%), and myelopathy 20/40 (50\%)). The other neurological features of Type 1 (classical) iSS included: bladder/bowel problems in $12 / 40(30 \%)$; swallowing problems in $3 / 40(8 \%)$. In the 17 patients in whom we had sufficient historical data to calculate the latency between the presumed casual event and onset of first symptoms, the median was 19 years (IQR 15 -27 years; range 4-50 years). All but one of patients with Type 1 (classical) iSS had symmetrical hemosiderin staining centered on the posterior fossa, with involvement of cerebellar folia, with a predilection for the superior vermis (Fig 3); a few also had less extensive supratentorial superficial siderosis and/or superficial siderosis of the cervical or thoracic spine (online supplementary Table 1).

\section{Type 2 (secondary) infratentorial superficial siderosis}

In 17 patients we identified a single episode of acute, spontaneous or traumatic (surgical) intracranial hemorrhage (spontaneous intracerebral hemorrhage $(n=8)$, aneurysmal subrachnoid hemorrhage $(n=6)$, intraventricular hemorrhage $(n=1)$, surgical trauma associated with removal of a pineal tumor $(\mathrm{n}=1)$, and bilateral subdural hemorrhages $(n=1)$, online supplementary Table 1). In all cases the intracranial hemorrhage was temporally and/or spatially associated with the radiological pattern of superficial siderosis, and judged by consensus to be a sufficient 
cause of the pattern of siderosis observed. In all of these patients the siderosis surrounding the site of intracranial bleeding was far more extensive than the infratentorial superficial siderosis (which, in most cases, consisted of a slender rim of hemosiderin, often centered on the $4^{\text {th }}$ ventricle outlet (Fig 4 , online supplementary Table 1)). None of the patients with Type 2 (secondary) iSS had a slowly progressive clinical syndrome, and none had any of the clinical features of "classical" superficial siderosis of the CNS. The mean time from the intracranial hemorrhage event to diagnosis on MRI for type 2 iSS was 25 months (range 11 days to 13 years).

Investigation findings in type 1 (classical) infratentorial superficial siderosis Cranial MRI

$48 / 48(100 \%)$ of the type 1 (classical) iSS patients underwent brain MR imaging. Of these, 45 patients $(94 \%)$ had paramagnetic sequences using either T2* or SWI. Although the "blooming artifact" with either T2* or SWI makes hemosiderin deposition far more visible (Fig 3), in our cohort there were no cases where siderosis was only visible on T2*/SWI and not T2-weighted MRI. Relevant presumed causal abnormalities were found on cranial MRI in 13/48 (27\%) patients. A sub-occipital meningocele was identified on cranial MRI in 12 patients (Fig 5, I and J); one patient had a large posterior fossa arachnoid cyst.

\section{Spinal MRI}

40/48 (83\%) classical iSS patients underwent spinal imaging, 27 of whom had high resolution MRI of the spine using either SPACE or CISS sequences. Potential causal abnormalities were noted in 25/48 (52\%) patients. An extra-arachnoid collection associated with a dural defect was identified in 21 patients (Fig 5 A-F: nine ventral spinal defects; seven posterior spinal defects; four nerve root pseudomeningoceles; and one anterior intracranial dural defect). Four patients had dural ectasia without an obvious frank dural defect (Fig $5 \mathrm{G}$ and $\mathrm{H}$ ).

\section{Intra-arterial digital subtraction angiography (IADSA)}

$11 / 48$ (23\%) type 1 (classical) iSS patients underwent intra-arterial digital substraction angiography (IADSA): six cerebral only; two spinal only; and three both cerebral and spinal. IADSA did not identify any potential cause for siderosis in any of 
the patients.

\section{CT myelography}

Five of 48 patients underwent CT myelography, which identified potential causal extra-arachnoid dural abnormalities in all patients: 2 patients had ventral thoracic extra-arachnoid collections; 2 had post-surgical posterior pseudomeningoceles; and 1 had a nerve root avulsion and pseudomeningocele. In the 2 ventral CSF collections, the precise site of the dural defect was not identified on conventional CT myelography; in one patient the precise site of dural defect was subsequently identified by direct injection of contrast into the CSF collection. (Fig 6)

\section{CSF analysis}

CSF was available in 17/48 (35\%) type 1 (classical) iSS patients (online supplement Table 1); in all cases tested, red blood cells were present but ferritin, oxyhemoglobin and bilirubin were only measured in a few selected cases. Where tested, ferritin was always raised; bilirubin was raised in $60 \%$ of patients tested, and oxyhemoglobin in $66 \%$ of patients tested. Due to the retrospective nature of this study, detailed data on CSF cell counts, opening pressure, etc. were not available due to limited clinical documentation.

\section{Presumed causes of type 1 (classical) infratentorial superficial siderosis}

A dural abnormality was the commonest finding, found in $40 / 48$ (83\%) of patients with type 1 (classical) iSS patients: eight were associated with previous spinal trauma; 21 with previous neurosurgery; three with both neurosurgery and spinal trauma; one with neurofibromatosis; one with Marfan's syndrome; two with ankylosing spondylitis; and four of the dural abnormalities had no obvious underlying cause.

Of the eight patients with no evidence of any definite dural abnormality, five had another potential cause of iSS identified; two pineal tumors (where the siderosis preceded any surgery); one spinal tumor (not operated upon); one partially thrombosed giant aneurysm with an enhancing wall, treated conservatively; and one slowly growing thalamostriate tumor, treated conservatively. Only three patients with classical iSS had no possible causative lesion on imaging, but none of these had 
adequate imaging of the spine.

Presumed causes of type 2 (secondary) infratentorial superficial siderosis

Type 2 (secondary) iSS is attributable to a clear single spontaneous or traumatic intracranial bleeding event (e.g. sub arachnoid hemorrhage, intracerebral hemorrhage, or surgery) where a significant volume of blood rapidly accumulates and "spills over" to be deposited in the subpial layers of supratentorial and infratentorial structures. By contrast with type 1 (classical) iSS, none of the patients with type 2 (secondary) iSS had any of the typical clinical features of classical superficial siderosis, or a progressive neurological deterioration. Furthermore, in type 2 (secondary) iSS the siderosis was mainly supratentorial, while the infratentorial component was generally a slender hemosiderin rim, often centered around the $4^{\text {th }}$ ventrical outlet. It seems very unlikely that a high-pressure arterial leak (e.g. from an aneurysm or arteriovenous malformation) of the type underlying type 2 (secondary) iSS could cause a continuous or highly repetitive low volume hemorrhage, which may explain the lack of association of secondary iSS with the classical slowly progressive clinical syndrome that is typical of type 1 (classical) iSS.

Results in the context of previous findings

To the best of our knowledge, the largest previous single series of patients with superficial siderosis included 30 participants. ${ }^{14}$ We are not aware of previous studies using a similar classification scheme for iSS ${ }^{9}$. The high incidence of dural abnormalities we found in type 1 (classical) iSS is consistent with a previous case series ${ }^{14}$ as well as a number of case reports ${ }^{16,17,22,23}$. Furthermore case reports show bleeding and venous abnormalities occur at the site of a dural tears 15, 16, 22, 24-26 27, 28 . However, our findings differ from some previous reports on the causes of type 1 (classical) iSS; although arteriovenous malformations have been reported to cause $9 \%$ of cases of superficial siderosis of the $\mathrm{CNS}^{9}$ we found none, and only one very atypical aneurysm, visible on plain MRI, with a contrast enhancing wall. There were no other cranial or spinal macrovascular lesions in our type 1 (classical) iSS cohort. While CAA has been suggested to account for 3\% of cases of superficial siderosis of the $\mathrm{CNS}^{9}$, we did not find any cases of CAA as a cause of type 1 (classical) iSS; moreover patients with CAA-related secondary iSS did not have any of the "classical" 
iSS clinical features of hearing loss, ataxia or myelopathy. We identified some rarer causes of type 1 (classical) iSS. Neurofibromatosis was the presumed cause of type 1 (classical) iSS in two patients, in keeping with previous single case reports. ${ }^{29}, 30$ Neurofibromatosis, ankylosing spondylosis, Marfan's syndrome and arachnoid cysts might all cause iSS by injury or distortion of the dura, leading to a weak point and a source of slow blood leakage through communication with the subarachnoid space.

Our clinical observations, including a long and slowly progressive history with a characteristic clinical syndrome as well as a symmetrical and stereotyped pattern of iSS, are consistent with the hypothesis that type 1 (classical) iSS results from continuous or repetitive low-volume subarachnoid hemorrhage which is disseminated and hemolysed in the CSF. This suggests the bleeding source is slow, under low pressure, probably of microvascular or venous origin, and most likely to arise in the spine or posterior fossa at the site of a dural defect. The lack of any macrovascular abnormalities on craniospinal IADSA in type 1 (classical) iSS argues against a macroscopic arterial bleeding point. In our series, neurosurgery, often many years prior to the development of clinical or radiological features of infratentorial superficial siderosis, was a common association with type 1 (classical) iSS.

\section{Strengths and limitations}

Our study has some important strengths; using overlapping methods of case ascertainment, we identified both consecutively referred and retrospectively identified patients over a long period, providing, to the best of our knowledge, the largest single reported case series of patients with iSS. We used pre-defined standardized radiological diagnostic criteria, with review (blinded to clinical details) by two certified consultant vascular neuroradiologists and a consultant vascular neurologist with a specialist interest in superficial siderosis.

Our study also has some limitations; we included referrals to a hospital specialist centre, which might cause selection bias. Our pre-specified radiological criteria are based upon consensus derived from previous publications and our extensive combined multidisciplinary team clinical experience, rather than a formal consensus 
group, and have not been validated in other populations. Clinical information from standard healthcare records may have been incomplete. We do not have long-term follow-up data to exclude the possibility that those with type 2 iSS might subsequently develop symptoms of type 1 (classical) iSS. However, we think that this is unlikely: firstly, none of the patients with type 2 (secondary) iSS presented with or subsequently developed any symptoms suggesting type 1 (classical) iSS (hearing loss, ataxia or myelopathy; and second, the radiological features, underlying causes and clinical presentations suggest that type 1 (classical) and type 2 (secondary) iSS are distinct entities. Finally, over the time period of the study, secular trends in investigation (e.g. the wider use of high resolution spinal imaging and CT myelography) may have affected our detection of potential underlying causes, though the high rate of finding an underlying diagnosis suggests that this was not a major problem.

\section{Clinical implications}

Our study, including a large case series of 65 patients with infratentorial superficial siderosis, confirms a broad clinical and radiological spectrum with numerous different causes. We build on previous observations on superficial siderosis by developing a classification, which we hope will be of value to clinicians faced with the clinical and radiological syndrome of iSS. Using simple pre-defined standardized radiological criteria, we describe two distinct groups of iSS based on presumed etiology, which have different clinical and radiological profiles: type 1 (classical) iSS occurs in the absence of any obvious single intracranial bleeding event and is associated with a slowly progressive neurological deterioration, usually including combinations of deafness, ataxia and myelopathy. Type 2 (secondary) iSS, is clearly attributable to a single spontaneous or post-traumatic intracranial bleeding event and is not associated with slowly progressive neurological deterioration. With a combination of targeted cranial and spinal imaging methods we found a likely underlying cause of iSS in $94 \%$ of patients with type 1 (classical) iSS. IADSA (catheter angiography) of the brain and/or spine did not contribute to detecting a cause for iSS in any patients in our cohort. 
Based on our observations, we also propose a rational diagnostic algorithm to follow when superficial siderosis is detected on imaging (Fig 7). Using this approach, we identified a cause for type 1 (classical) superficial siderosis in 45 of 48 patients (94\%). The very small proportion without an underlying diagnosis in our series (three patients, $6 \%$ ) is much lower than the $35 \%$ of unexplained or "idiopathic" cases suggested in the literature. ${ }^{9}$ Furthermore, these three patients did not have adequate spinal MRI available, so might have had a cause identified if our recommended algorithm was followed. The high diagnostic yield (and frequent finding of dural abnormalities) in our study is likely due to our systematic use of cranial and spinal imaging.

While there is no treatment proven to alter the natural history of classical infratentorial superficial siderosis, there is preliminary evidence for the safety and tolerability of deferiprone, an iron-chelating drug, which crosses the blood brain barrier ${ }^{31-33}$. Although iron chelation has unproven efficacy in iSS, it has been associated with possible clinical or radiological improvement ${ }^{31-36}$ and decreased ferritin in the CSF. ${ }^{37}$ However, agranulocytosis is a potentially serious side effect of deferiprone. ${ }^{35}$ Thus, whether iron chelation might lead to clear clinical benefit in iSS remains unproven; randomized controlled trials are needed to test this hypothesis, but will be challenging due to the rarity and slow progression of iSS. An observational trial of deferiprone in superficial siderosis (ClinicalTrials.gov Identifier: NCT01284127), with a planned follow up period of 2 years, has completed recruitment but is not yet published. Iron chelation therapy has also been investigated in other neurological disorders including neurodegeneration with brain iron accumulation; although it can decrease cerebral iron content assessed by MRI, there is currently no compelling evidence that iron removal has beneficial effects in any neurological disorder. ${ }^{38}$

Observational reports suggest that defining and treating causal structural anomalies (e.g. surgical repair or blood patches to seal dural defects ${ }^{17}$ ) might be of benefit, but large scale controlled studies are lacking. Nevertheless, we suggest that it is important to recognize the typical clinical and radiological pattern of type 1 (classical) iSS to ensure rational investigation, timely diagnosis and early consideration of treatment (ideally in the context of randomised controlled trials); our proposed diagnostic 
criteria and investigation pathway should help to facilitate this goal.
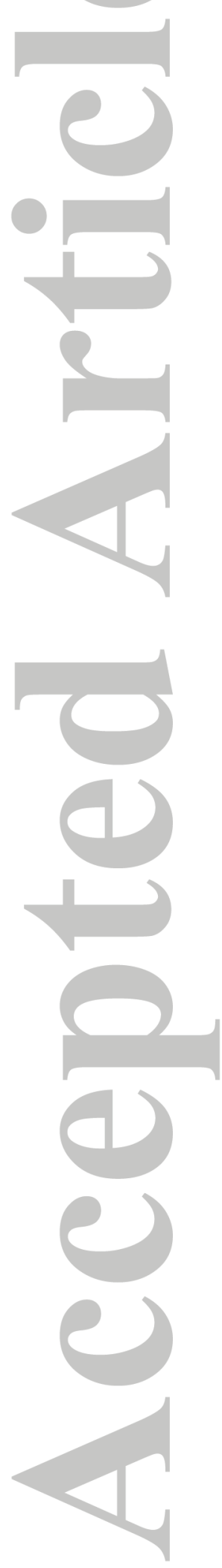

John Wiley \& Sons

This article is protected by copyright. All rights reserved. 


\section{Acknowledgements}

SFF and DJW acknowledge support from UCLH Biomedical Research Centre. The authors thank Dr Gargi Banerjee for drafting Figure 1. There was no specific funding for this study. DW and DJW receive funding from the Stroke Association and British Heart Foundation.

\section{Author Contributions}

DW, PC and DJW were involved with study concept and design; data acquisition, analysis; and drafting the manuscript and figures. FC, SFF, PR and MOM were involved with data acquisition and analysis; and drafting the manuscript

\section{Potential conflicts of interest}

None of the authors declare any conflict of interests.

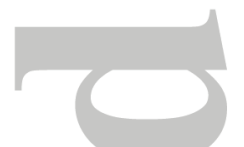

\section{Figure Titles and Legends}

Figure 1: Pathophysiology of type 1 classical infratentorial siderosis

Figure 2: Flow chart of patients in study.

Figure 3: Type 1 (classical) infratentorial superficial siderosis shown on T2-weighted axial magnetic resonance image (A) and corresponding T2*-weighted GRE magnetic resonance image (B) showing the typical pattern of hemosiderin centered on the cerebellar vermis (white arrows). Note the "blooming effect on the T2*-weighted GRE image (B) compared to the T2-weighted image (A).

Legend: GRE -gradient recalled echo

Figure 4: Type 2 (secondary) infratentorial superficial siderosis, caused by a deep basal ganglia intracerebral hemorrhage, shown on axial T2*-weighted GRE magnetic resonance images. Note that the infratentorial superficial siderosis consists of only a 
slender rim of hemosiderin, centered around the fourth ventricle outlet and extending towards the cranio-cervical junction (white arrows)

Legend: GRE -gradient recalled echo

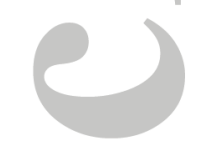

Figure 5: Imaging examples of dural defects associated with infratentorial superficial siderosis. (A) and (B) show a nerve root pseudomeningocele (white arrow) on sagittal T2-weighted spinal MRI (A) and axial T2-weighted spinal MRI (B); (C) and (D) show a large posterior spinal CSF collection (white arrow) on sagittal T2-weighted spinal MRI (C) and axial T2-weighted spinal MRI (D); (E) and (F) show an anterior spinal CSF collection (white arrow) - in this patient probably related to previous trauma - on sagittal T2-weighted spinal MRI (E) and axial T2-weighted spinal MRI $(\mathrm{F})$; $(\mathrm{G})$ and $(\mathrm{H})$ show dural ectasia in a patient with Marfan's syndrome (white arrow) on sagittal T2-weighted spinal MRI (G) and axial T2-weighted spinal MRI (H); (I) and (J) show a sub-occipital pseudomeningocele on axial T2-weighted MRI (I) and sagittal T2-weighted MRI with associated siderosis over the superior folia of the cerebellar vermis.

Figure 6: CT myelography in the investigation of infratentorial superficial siderosis: (A) CT myelography showing ventral extra-arachnoid spinal collection in the upper thoracic region; (B) Transforaminal injection into the ventral extra-arachnoid collection; (C) MRI image showing ventral extra-arachnoid spinal collection (note that differentiation of extra arachnoid CSF collection from epidural fat can be difficult); (D) Direct injection of dense contrast into the ventral upper thoracic collection fills the cavity in a gravity-dependent fashion (the arrow shows the point at which the contrast first enters the sub-arachnoid space at T2/3, revealing the precise level of the dural defect).

Figure 7: Proposed investigation and treatment algorithm in patients with superficial siderosis detected on neuroimaging

Legend: CAA-cerebral amyloid angiopathy, RCVS-reversible cerebral vasoconstriction syndrome, IADSA-intra-arterial digital subtraction angiography, CISS - Constructive Interference in Steady State, SPACE - Single-Slab 3- 


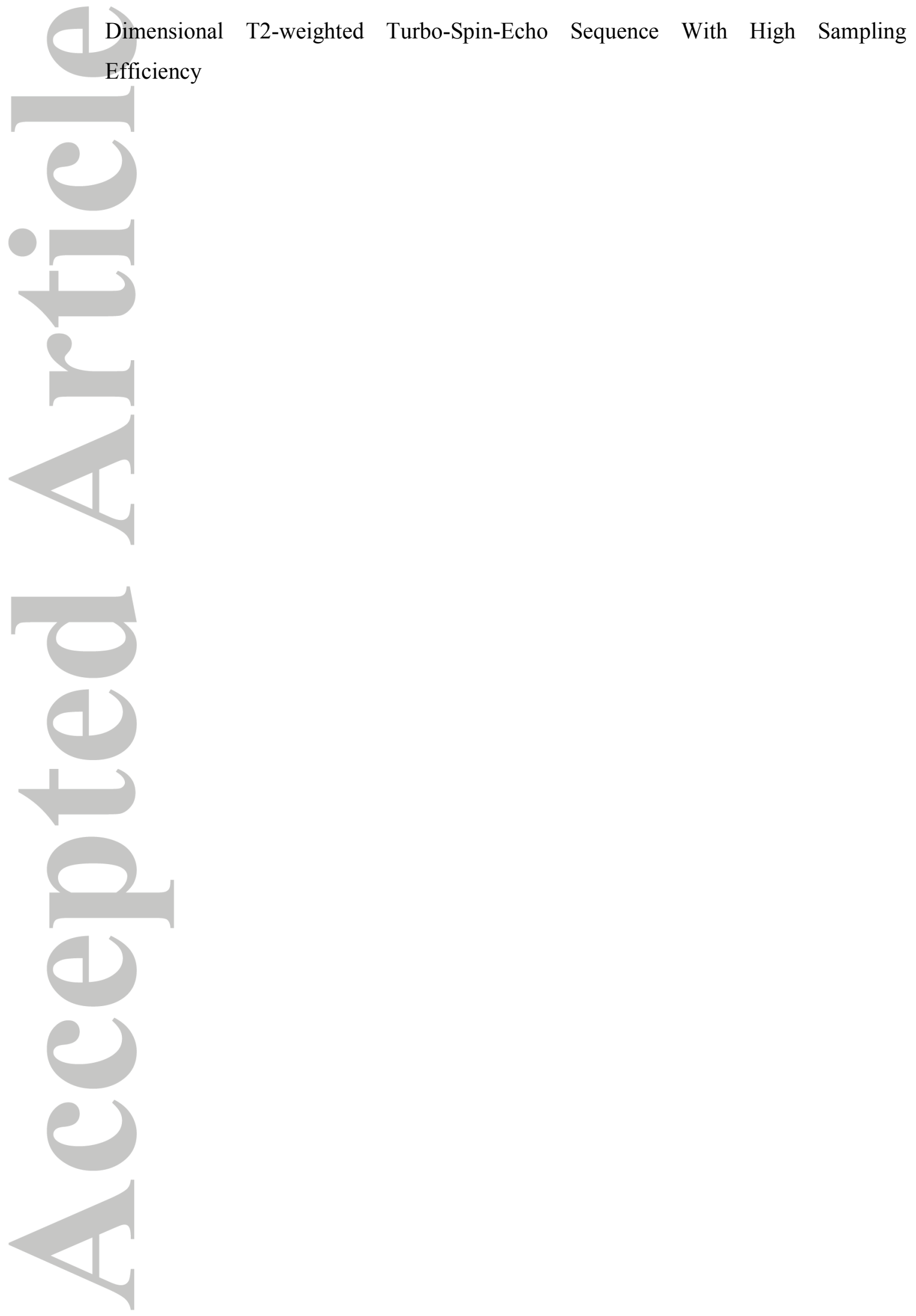

John Wiley \& Sons

This article is protected by copyright. All rights reserved. 


\section{References}

1. Fearnley JM, Stevens JM, Rudge P. Superficial siderosis of the central nervous system. Brain : a journal of neurology. 1995 Aug;118 ( Pt 4):1051-66.

2. Hamill RC. Report of a case of melanosis of the brain, cord and meninges. J Nerv Ment Dis. 1908(35):594.

3. Iwanowski L, Olszewski J. The effects of subarachnoid injections of ironcontaining substances on the central nervous system. Journal of neuropathology and experimental neurology. $1960 \mathrm{Jul} ; 19: 433-48$.

4. Koeppen AH, Dickson AC, Chu RC, Thach RE. The pathogenesis of superficial siderosis of the central nervous system. Annals of neurology. 1993 Nov;34(5):646-53.

5. Koeppen AH, Dentinger MP. Brain hemosiderin and superficial siderosis of the central nervous system. Journal of neuropathology and experimental neurology. 1988 May;47(3):249-70.

6. Milhorat TH HM. Cerebrospinal fluid as reflection of internal milieu of brain. In: JH W, editor. Neurobiology of cerebrospinal fluid: Plenum Press, New York, ; 1983. p. pp 1-23.

7. Koeppen AH, Michael SC, Li D, et al. The pathology of superficial siderosis of the central nervous system. Acta neuropathologica. 2008 Oct;116(4):371-82.

8. Tarlov I. Structure of the nerve root 1. Nature of the junction between the central and peripheral nervous system. Arch Neurol Psychiatry. 1937;37:555-83.

9. Levy M, Turtzo C, Llinas RH. Superficial siderosis: a case report and review of the literature. Nature clinical practice Neurology. 2007 Jan;3(1):54-8.

10. Hughes JT, Oppenheimer DR. Superficial siderosis of the central nervous system. A report on nine cases with autopsy. Acta neuropathologica. 1969;13(1):5674.

11. Linn J, Halpin A, Demaerel P, et al. Prevalence of superficial siderosis in patients with cerebral amyloid angiopathy. Neurology. 2010 Apr 27;74(17):1346-50.

12. Charidimou A, Peeters AP, Jager R, et al. Cortical superficial siderosis and intracerebral hemorrhage risk in cerebral amyloid angiopathy. Neurology. 2013 Nov 5;81(19):1666-73.

13. Charidimou A, Peeters A, Fox Z, et al. Spectrum of transient focal neurological episodes in cerebral amyloid angiopathy: multicentre magnetic resonance imaging cohort study and meta-analysis. Stroke; a journal of cerebral circulation. 2012 Sep;43(9):2324-30.

14. Kumar N, Cohen-Gadol AA, Wright RA, Miller GM, Piepgras DG, Ahlskog JE. Superficial siderosis. Neurology. 2006 Apr 25;66(8):1144-52.

15. Kumar N, Miller GM, Piepgras DG, Mokri B. A unifying hypothesis for a patient with superficial siderosis, low-pressure headache, intraspinal cyst, back pain, and prominent vascularity. Journal of neurosurgery. $2010 \mathrm{Jul}$;113(1):97-101.

16. Kumar N, Lindell EP, Wilden JA, Davis DH. Role of dynamic CT myelography in identifying the etiology of superficial siderosis. Neurology. 2005 Aug 9;65(3):486-8.

17. Kumar N, Lane JI, Piepgras DG. Superficial siderosis: sealing the defect. Neurology. 2009 Feb 17;72(7):671-3.

18. Holle D, Sandalcioglu IE, Gizewski ER, et al. Association of superficial siderosis of the central nervous system and low pressure headache. Journal of neurology. 2008 Jul;255(7):1081-2. 
19. Hoxworth JM, Patel AC, Bosch EP, Nelson KD. Localization of a rapid CSF leak with digital subtraction myelography. AJNR American journal of neuroradiology. 2009 Mar;30(3):516-9.

20. Kumar N. Neuroimaging in superficial siderosis: an in-depth look. AJNR American journal of neuroradiology. $2010 \mathrm{Jan} ; 31(1): 5-14$.

21. Charidimou A, Linn J, Vernooij MW, et al. Cortical superficial siderosis: detection and clinical significance in cerebral amyloid angiopathy and related conditions. Brain : a journal of neurology. 2015 Aug;138(Pt 8):2126-39.

22. Wilden JA, Kumar N, Murali HR, Lindell EP, Davis DH. Unusual neuroimaging in superficial siderosis. Neurology. 2005 Aug 9;65(3):489.

23. Kumar N. Superficial siderosis: associations and therapeutic implications. Archives of neurology. 2007 Apr;64(4):491-6.

24. Payer M, Sottas C, Bonvin C. Superficial siderosis of the central nervous system: secondary progression despite successful surgical treatment, mimicking amyotrophic lateral sclerosis. Case report and review. Acta neurochirurgica. 2010 Aug;152(8):1411-6.

25. Kumar N, McKeon A, Rabinstein AA, Kalina P, Ahlskog JE, Mokri B. Superficial siderosis and csf hypovolemia: the defect (dural) in the link. Neurology. 2007 Aug 28;69(9):925-6.

26. Cheng CY, Chen MH, Wang SJ, Lin KP. A proposed mechanism of superficial siderosis supported by surgical and neuroimaging findings. Medical hypotheses. 2011 Jun;76(6):823-6.

27. Boncoraglio GB, Ballabio E, Erbetta A, Prada F, Savoiardo M, Parati EA. Superficial siderosis due to dural defect with thoracic spinal cord herniation. Journal of the neurological sciences. 2012 Jan 15;312(1-2):170-2.

28. Shih P, Yang BP, Batjer HH, Liu JC. Surgical management of superficial siderosis. The spine journal : official journal of the North American Spine Society. 2009 Aug;9(8):e16-9.

29. Matsumoto A, Suzuki H, Tobita M, Hisanaga K. An autopsy case of superficial siderosis of the central nervous system accompanied by anterior sacral polycystic meningocele in neurofibromatosis type 1 . Rinsho shinkeigaku $=$ Clinical neurology. 2016 Jul 28;56(7):486-94.

30. Manfredi M, De Togni L, Beltramello A. Superficial siderosis of the central nervous system in a patient with neurofibromatosis type I. European neurology. 2000;43(2):121-2.

31. Levy M, Llinas R. Pilot safety trial of deferiprone in 10 subjects with superficial siderosis. Stroke; a journal of cerebral circulation. 2012 Jan;43(1):120-4.

32. Levy M, Llinas RH. Update on a patient with superficial siderosis on deferiprone. AJNR American journal of neuroradiology. 2012 Jun;33(6):E99-100.

33. Levy M, Llinas RH. Deferiprone reduces hemosiderin deposits in the brain of a patient with superficial siderosis. AJNR American journal of neuroradiology. 2011 Jan;32(1):E1-2.

34. Cummins G, Crundwell G, Baguley D, Lennox G. Treatment of superficial siderosis with iron chelation therapy. BMJ case reports. 2013 Jul 09;2013.

35. Huprikar N, Gossweiler M, Callaghan M, Bunge P. Agranulocytosis with deferiprone treatment of superficial siderosis. BMJ case reports. 2013 Aug 07;2013.

36. Kuo PH, Kuo SH, Lo RY. Deferiprone Reduces Hemosiderin Deposition in Superficial Siderosis. The Canadian journal of neurological sciences Le journal canadien des sciences neurologiques. 2016 Oct 28:1-2. 
37. Schirinzi T, Sancesario G, Anemona L, Pisani A, Sancesario G. CSF biomarkers in superficial siderosis: a new tool for diagnosis and evaluation of therapeutic efficacy of deferiprone--a case report. Neurological sciences : official journal of the Italian Neurological Society and of the Italian Society of Clinical Neurophysiology. 2014 Jul;35(7):1151-2.

38. Dusek P, Schneider SA, Aaseth J. Iron chelation in the treatment of neurodegenerative diseases. Journal of trace elements in medicine and biology : organ of the Society for Minerals and Trace Elements. 2016 Dec;38:81-92.
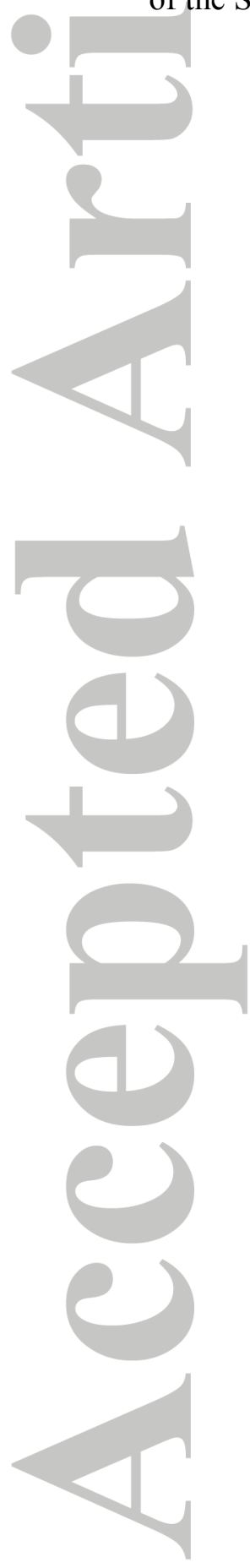


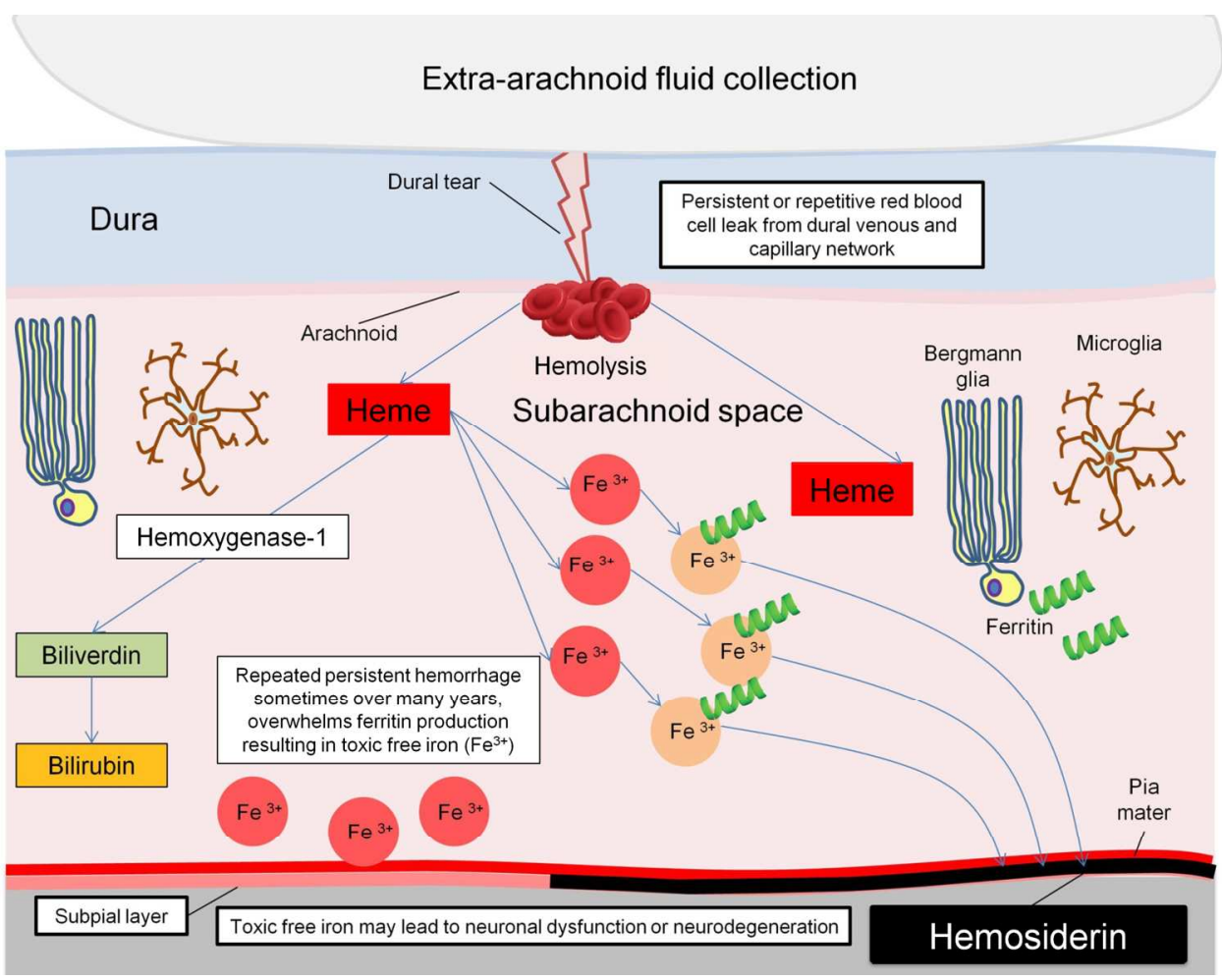

Pathophysiology of type 1 classical infratentorial siderosis

Fig 1

$170 \times 127 \mathrm{~mm}(300 \times 300 \mathrm{DPI})$ 


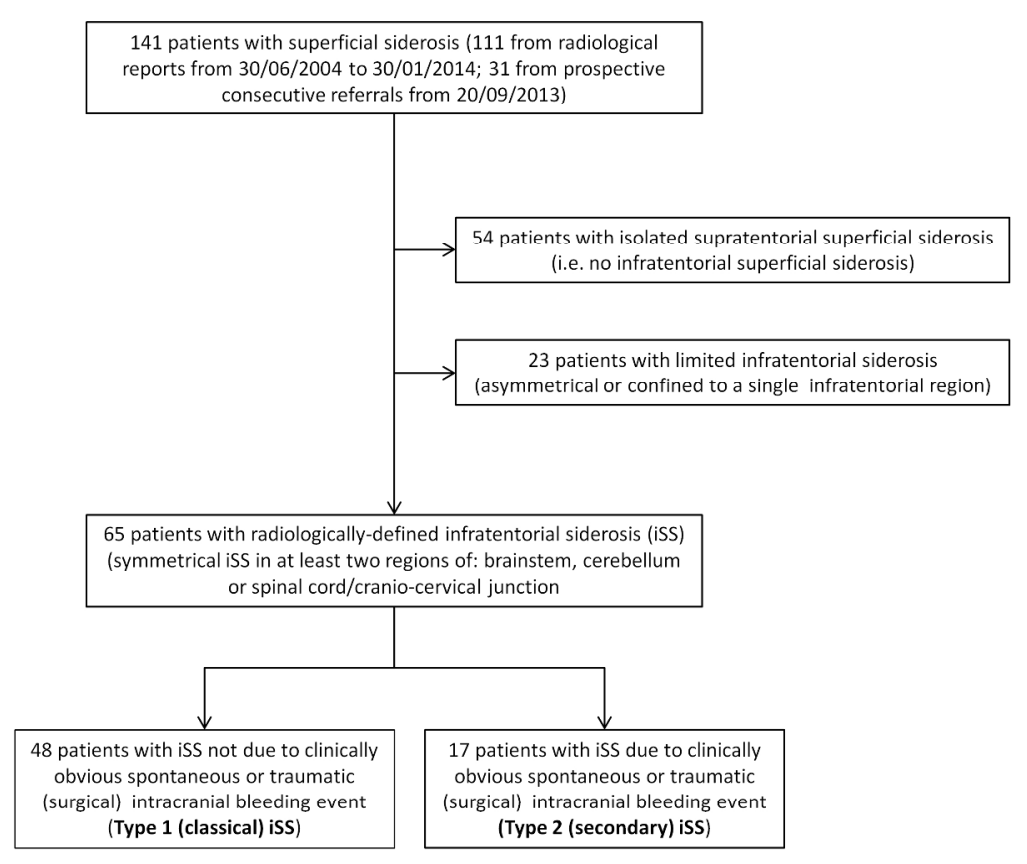

Flow chart of patients in study.

Fig 2

$254 \times 190 \mathrm{~mm}(300 \times 300$ DPI $)$

\section{John Wiley \& Sons}

This article is protected by copyright. All rights reserved. 


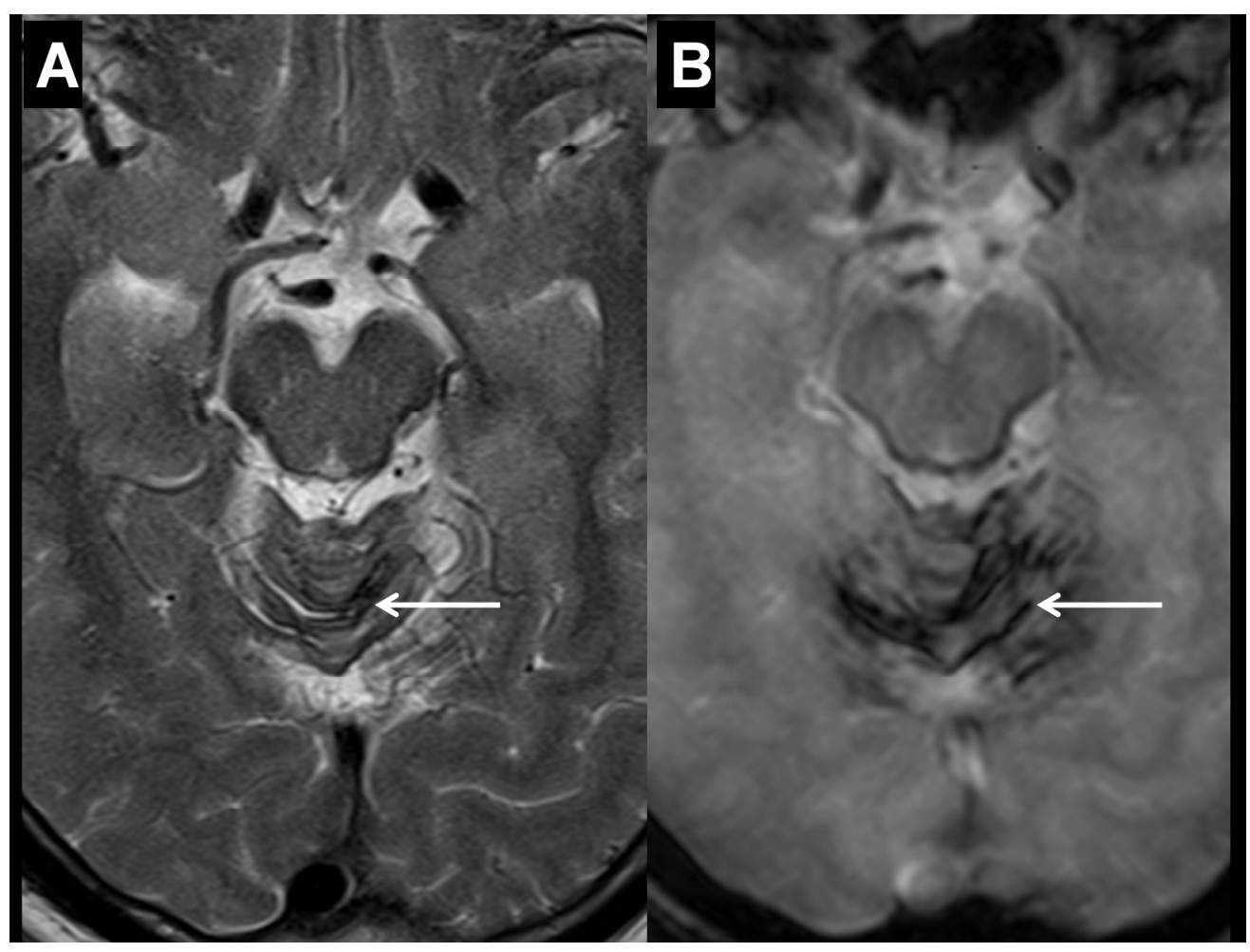

Type 1 (classical) infratentorial superficial siderosis shown on T2-weighted axial magnetic resonance image (A) and corresponding T2*-weighted GRE magnetic resonance image (B) showing the typical pattern of hemosiderin centered on the cerebellar vermis (white arrows). Note the "blooming effect on the T2*weighted GRE image (B) compared to the T2-weighted image (A). Legend: GRE -gradient recalled echo

Fig 3

$254 \times 190 \mathrm{~mm}$ ( $300 \times 300$ DPI) 


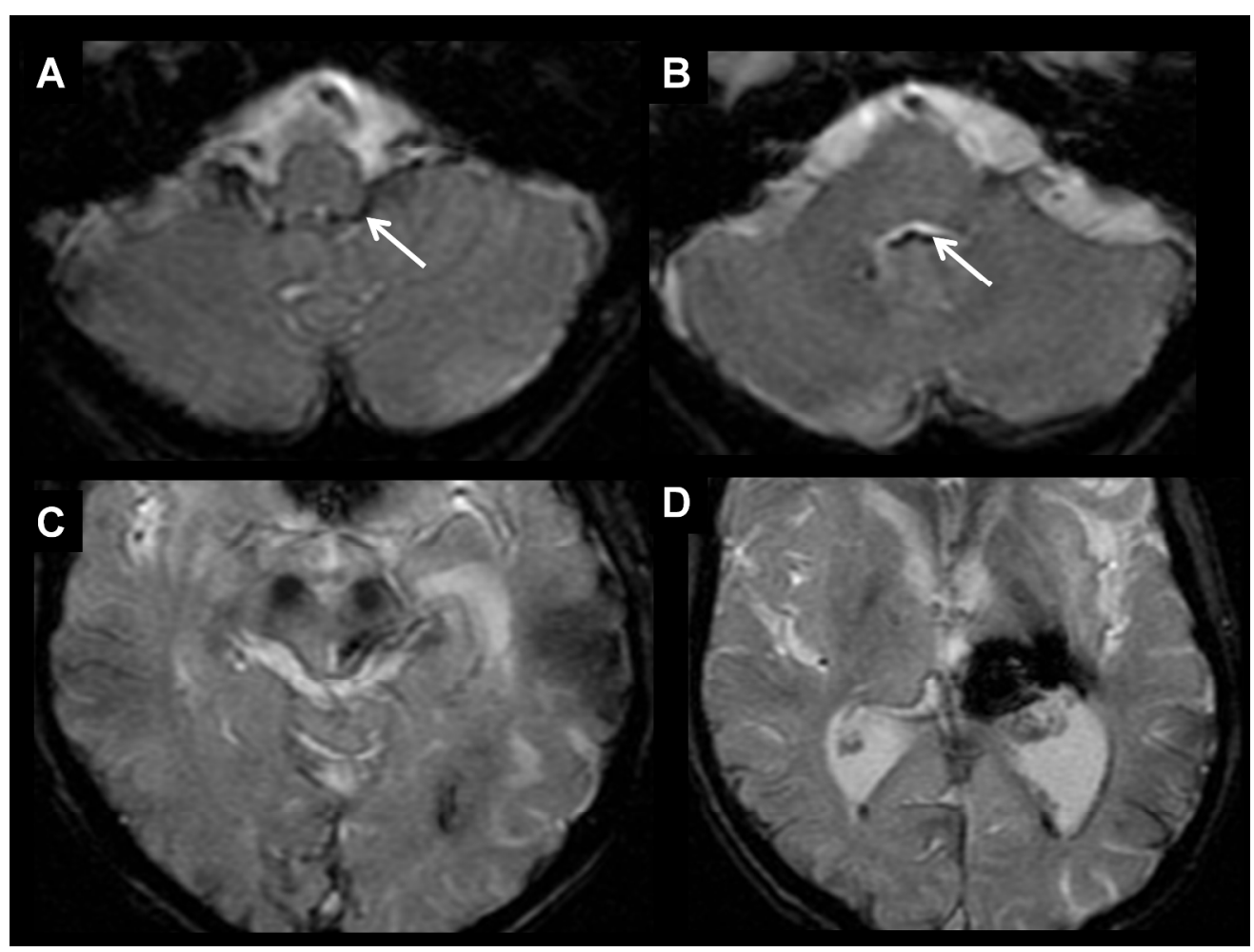

Type 2 (secondary) infratentorial superficial siderosis, caused by a deep basal ganglia intracerebral hemorrhage, shown on axial T2*-weighted GRE magnetic resonance images. Note that the infratentorial superficial siderosis consists of only a slender rim of hemosiderin, centered around the fourth ventricle outlet and extending towards the cranio-cervical junction (white arrows)

Legend: GRE -gradient recalled echo

Fig 4

$254 \times 190 \mathrm{~mm}(300 \times 300$ DPI $)$ 


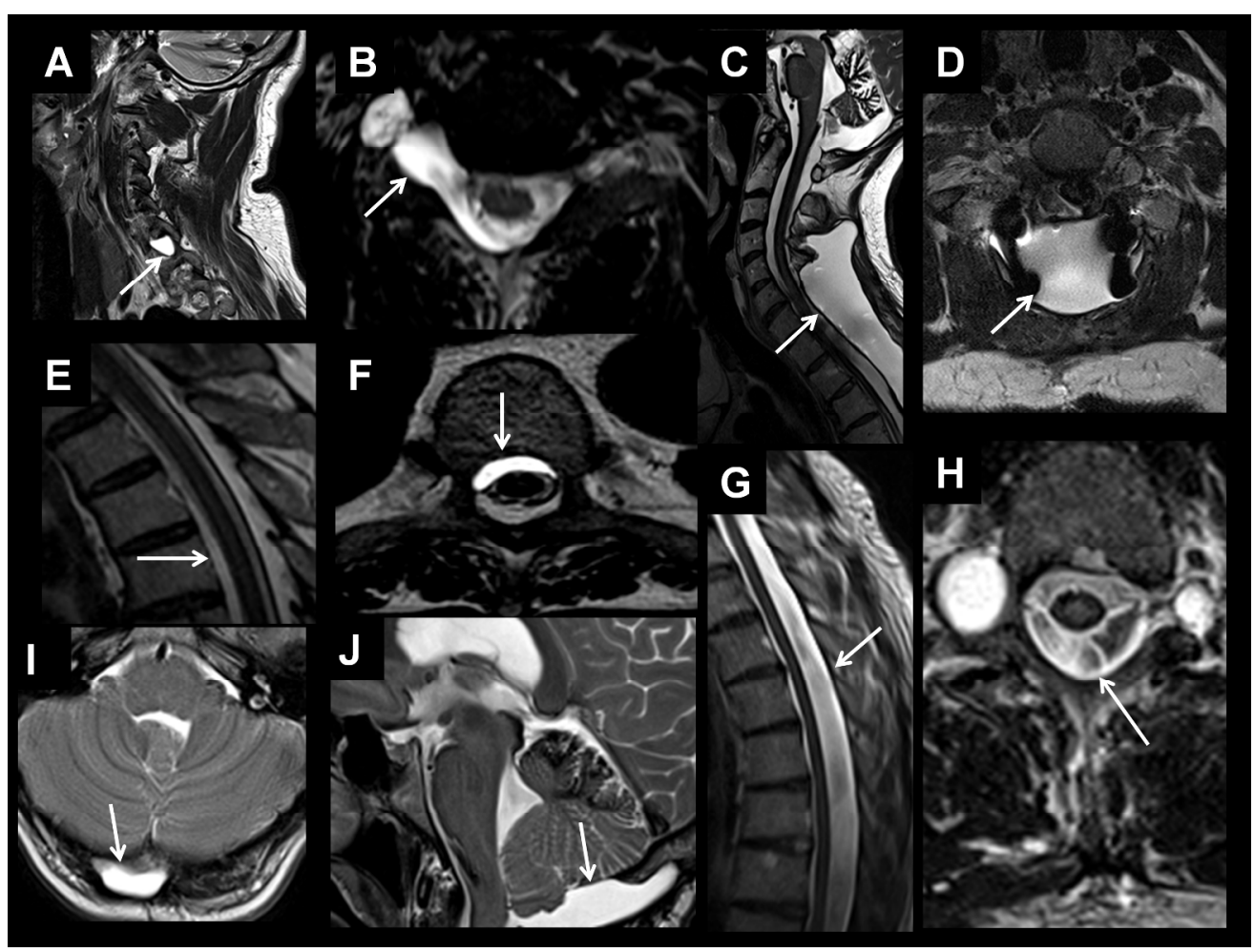

Imaging examples of dural defects associated with infratentorial superficial siderosis. (A) and (B) show a nerve root pseudomeningocele (white arrow) on sagittal T2-weighted spinal MRI (A) and axial T2-weighted

spinal MRI (B); (C) and (D) show a large posterior spinal CSF collection (white arrow) on sagittal T2-

weighted spinal MRI (C) and axial T2-weighted spinal MRI (D); (E) and (F) show an anterior spinal CSF collection (white arrow) - in this patient probably related to previous trauma - on sagittal T2-weighted spinal MRI (E) and axial T2-weighted spinal MRI (F); (G) and (H) show dural ectasia in a patient with Marfan's syndrome (white arrow) on sagittal T2-weighted spinal MRI (G) and axial T2-weighted spinal MRI (H); (I) and ( $\mathrm{J}$ ) show a sub-occipital pseudomeningocele on axial T2-weighted MRI (I) and sagittal T2-weighted MRI with associated siderosis over the superior folia of the cerebellar vermis.

Fig 5

$254 \times 190 \mathrm{~mm}(300 \times 300 \mathrm{DPI})$

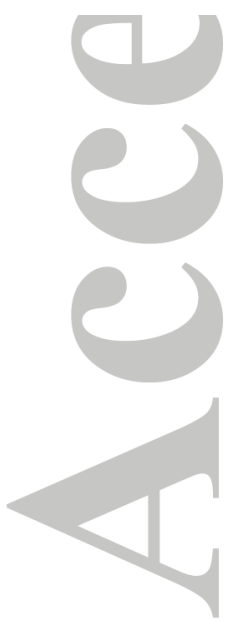




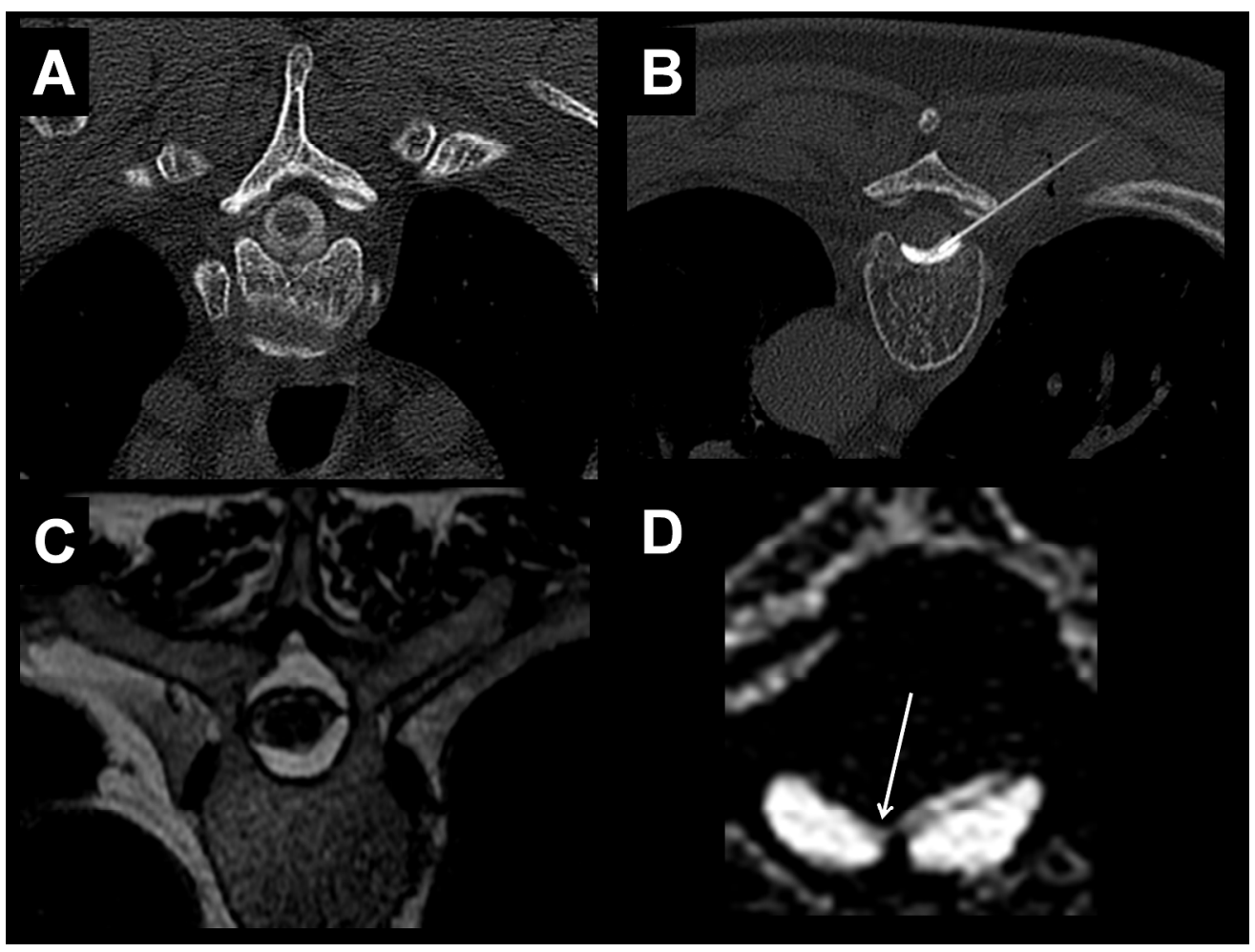

CT myelography in the investigation of infratentorial superficial siderosis: (A) CT myelography showing ventral extra-arachnoid spinal collection in the upper thoracic region; (B) Transforaminal injection into the ventral extra-arachnoid collection; (C) MRI image showing ventral extra-arachnoid spinal collection (note that differentiation of extra arachnoid CSF collection from epidural fat can be difficult); (D) Direct injection of dense contrast into the ventral upper thoracic collection fills the cavity in a gravity-dependent fashion (the arrow shows the point at which the contrast first enters the sub-arachnoid space at T2/3, revealing the precise level of the dural defect).

Fig 6

$254 \times 190 \mathrm{~mm}(300 \times 300 \mathrm{DPI})$ 


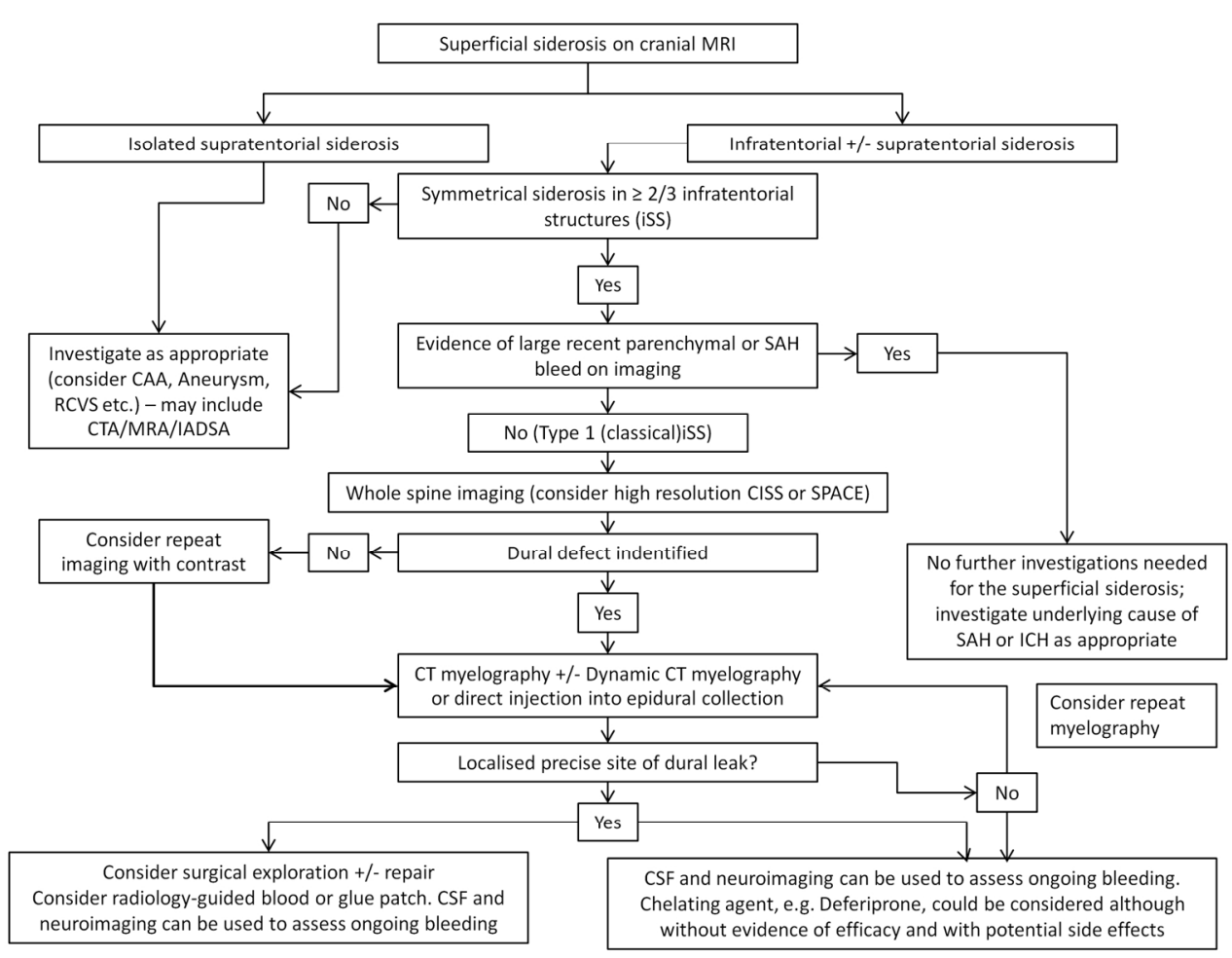

Proposed investigation and treatment algorithm in patients with superficial siderosis detected on neuroimaging

- Legend: CAA-cerebral amyloid angiopathy, RCVS-reversible cerebral vasoconstriction syndrome, IADSAintra-arterial digital subtraction angiography, CISS - Constructive Interference in Steady State, SPACE -

Single-Slab 3-Dimensional T2-weighted Turbo-Spin-Echo Sequence With High Sampling Efficiency

Fig 7

$170 \times 127 \mathrm{~mm}(300 \times 300 \mathrm{DPI})$

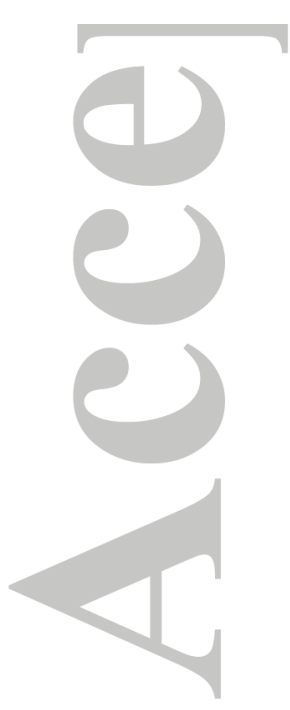

This article is protected by copyright. All rights reserved. 


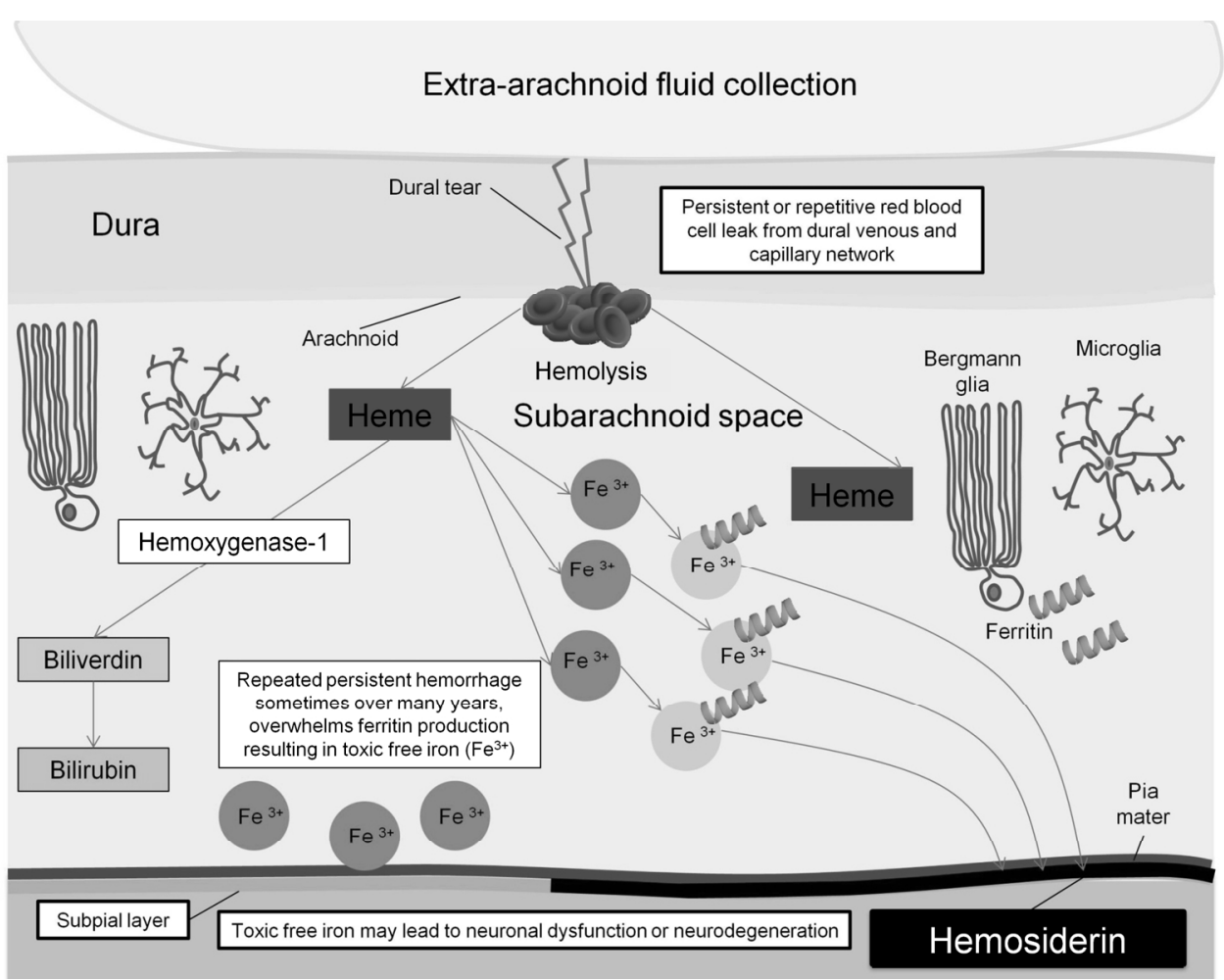

Pathophysiology of type 1 classical infratentorial siderosis (Greyscale version for print) Fig 1

$170 \times 127 \mathrm{~mm}(300 \times 300 \mathrm{DPI})$ 


\section{Table 1. Causes of superficial siderosis in all patients identified from our prospective consecutive registry and retrospective radiological search.}

\begin{tabular}{|c|c|c|c|c|}
\hline $\begin{array}{l}\text { Presumed cause of } \\
\text { superficial siderosis }\end{array}$ & $\begin{array}{c}\text { Isolated } \\
\text { supratentorial } \\
\text { superficial siderosis, } \\
\mathbf{n}=\mathbf{5 4}\end{array}$ & $\begin{array}{c}\text { Restricted } \\
\text { infratentorial } \\
\text { superficial siderosis } \\
\text { not fulfilling } \\
\text { diagnostic criteria, } \\
\mathbf{n}=\mathbf{2 3}\end{array}$ & $\begin{array}{c}\text { Type } 1 \text { (classical) } \\
\text { infratentorial } \\
\text { superficial siderosis, } \\
\mathbf{n}=\mathbf{4 8}\end{array}$ & $\begin{array}{c}\text { Type } 2 \text { (secondary) } \\
\text { infratentorial } \\
\text { superficial siderosis, } \\
\mathbf{n}=17\end{array}$ \\
\hline $\begin{array}{l}\text { Intracerebral } \\
\text { Hemorrhage }(+/- \\
\text { convexity SAH) }\end{array}$ & $28(52 \%)$ & $6(26 \%)$ & 0 & $9(53 \%)$ \\
\hline Traumatic contusions & $16(30 \%)$ & $3(13 \%)$ & 0 & 0 \\
\hline Aneurysmal SAH & $5(9 \%)$ & $3(13 \%)$ & $\begin{array}{c}1(2 \%) \text { atypical } \\
\text { aneurysm with slow } \\
\text { rather than acute SAH }\end{array}$ & $6(35 \%)$ \\
\hline Ruptured AVM & $2(4 \%)$ & $1(4 \%)$ & 0 & 0 \\
\hline $\begin{array}{l}\text { Cerebral Venous } \\
\text { Sinus Thrombosis }\end{array}$ & $1(2 \%)$ & $1(4 \%)$ & 0 & 0 \\
\hline $\begin{array}{l}\text { Non aneurysmal } \\
\text { (perimesencephalic) } \\
\text { SAH }\end{array}$ & 0 & $1(4 \%)$ & 0 & 0 \\
\hline $\begin{array}{l}\text { Surgical trauma } \\
\text { directly causing } \\
\text { hemorrhage and } \\
\text { related siderosis }\end{array}$ & $2(4 \%)$ & $4(17 \%)$ & 0 & $1(6 \%)$ \\
\hline Subdural hemorrhage & 0 & $1(4 \%)$ & 0 & $1(6 \%)$ \\
\hline Dural abnormality ${ }^{*}$ & 0 & 0 & $40(83 \%)$ & 0 \\
\hline Tumor & 0 & 0 & $4(9 \%)$ & 0 \\
\hline $\begin{array}{l}\text { Spinocerebellar ataxia } \\
\text { with associated brain } \\
\text { iron accumulation }\end{array}$ & 0 & $1(4 \%)$ & 0 & 0 \\
\hline $\begin{array}{l}\text { Hemorrhagic } \\
\text { transformation of an } \\
\text { infarct }\end{array}$ & 0 & $1(4 \%)$ & 0 & 0 \\
\hline Cause identified & $54(100 \%)$ & $22(96 \%)$ & $45(94 \%)$ & $17(100 \%)$ \\
\hline No cause identified & $\mathbf{0}$ & $1(4 \%)$ & $\begin{array}{l}3(6 \%) \text {; (none had } \\
\text { adequate spinal } \\
\text { imaging) }\end{array}$ & $\mathbf{0}$ \\
\hline
\end{tabular}

* Dural abnormalities included the following: pseudomeningocoele; extra-arachnoid CSF collection; dural ectasia, etc. Some of these dural abnormalities were related to previous surgery or trauma, often many years earlier (see Online Supplementary Table 1 for details).

** These patients had infratentorial superficial siderosis which was not present bilaterally (symmetrically) in at least two of the following regions: (1) brainstem (including midbrain, pons, medulla); (2) cerebellum (including the cerebellar folia, vermis, and cerebellar peduncles); and (3) spinal cord or cranio-cervical junction. 
Supplementary Table 1: Characteristics of the patients with Type 1 (classical) and Type 2 (secondary) infratentorial superficial siderosis.

\begin{tabular}{|c|c|c|c|c|c|c|}
\hline & $\begin{array}{c}\text { Siderosis pattern } \\
\text { (qualitative burden, presumed } \\
\text { epicentre, extension supra or } \\
\text { infratentorially) }\end{array}$ & $\begin{array}{l}\text { Symptoms of classical } \\
\text { infratentorial } \\
\text { superficial siderosis } \\
\text { (hearing loss, ataxia, } \\
\text { myelopathy) }\end{array}$ & $\begin{array}{l}\text { History of cranial- } \\
\text { spinal trauma or } \\
\text { surgery }\end{array}$ & $\begin{array}{c}\text { Latency between } \\
\text { known antecedent } \\
\text { event (trauma, } \\
\text { surgery) and } \\
\text { symptoms or } \\
\text { diagnosis }\end{array}$ & Likely cause of siderosis & CSF findings \\
\hline 1 & Severe, centred on posterior fossa & $\begin{array}{l}\text { Hearing loss, myelopathy, } \\
\text { ataxia, sphincter symptoms }\end{array}$ & $\begin{array}{l}\text { Cerebellar pilocytic } \\
\text { astrocytoma excised }\end{array}$ & Unknown & $\begin{array}{l}\text { Suboccipital pseudomeningocele } \\
\text { following neurosurgery }\end{array}$ & $\begin{array}{l}\text { Xanthochromia, } \\
\text { ferritin } 134, \text { red } \\
\text { cells } 10750\end{array}$ \\
\hline 2 & $\begin{array}{l}\text { Moderate/severe, hemosiderin centred on } \\
\text { the posterior fossa }\end{array}$ & Ataxia and myelopathy & Occipital craniotomy & Unknown & $\begin{array}{l}\text { Suboccipital pseudomeningocele } \\
\text { following neurosurgery }\end{array}$ & Not available \\
\hline 3 & $\begin{array}{l}\text { Moderate, centred on the posterior fossa } \\
\text { with involvement of the spine }\end{array}$ & $\begin{array}{l}\text { Hearing loss, ataxia, } \\
\text { myelopathy, urinary } \\
\text { symptoms, fatigue, headaches }\end{array}$ & No & Not applicable & Posterior fossa arachnoid cyst & Not available \\
\hline 4 & Severe, centred on posterior fossa & $\begin{array}{l}\text { Ataxia and hearing loss and } \\
\text { detruser instability }\end{array}$ & $\begin{array}{l}\text { Occipital craniectomy } \\
\text { for Chiari Type } 1 \\
\text { malformation }\end{array}$ & Unknown & $\begin{array}{l}\text { Suboccipital pseudomeningocele } \\
\text { following neurosurgery }\end{array}$ & $\begin{array}{l}\text { Xanthochromia, } \\
\text { spectophotometric } \\
\text { peak consistent } \\
\text { with bilirubin }\end{array}$ \\
\hline 5 & $\begin{array}{l}\text { Moderate, centred on the posterior fossa. } \\
\text { Less prominent siderosis extends to the } \\
\text { cervical spine inferiorly and the Sylvian } \\
\text { fissures supratentorially }\end{array}$ & $\begin{array}{l}\text { Hearing loss, ataxia, urinary } \\
\text { symptoms, diplopia }\end{array}$ & $\begin{array}{l}\text { RTA Fracture } \mathrm{C} 2 / 3 \text {. } \\
\text { Spinal surgery } \\
\text { cauterisation of bleeding } \\
\text { point }\end{array}$ & 20 years & $\begin{array}{l}\text { Ventral spinal dural defect, } \\
\text { secondary to spinal trauma }\end{array}$ & Not available \\
\hline 6 & $\begin{array}{l}\text { Moderate, centred on the posterior fossa. } \\
\text { Less prominent siderosis extends to the } \\
\text { cervical spine inferiorly and the Sylvian } \\
\text { fissures supratentorially }\end{array}$ & Hearing loss & $\begin{array}{l}\text { Spinal surgery for } \\
\text { diastomatomyelia at age } \\
2 \text { years }\end{array}$ & Unknown & $\begin{array}{l}\text { Spinal dural defect following } \\
\text { surgery }\end{array}$ & Not available \\
\hline 7 & $\begin{array}{l}\text { Mild, hemosiderin centred on the } \\
\text { posterior fossa }\end{array}$ & Gait deterioration & No & Not applicable & $\begin{array}{l}\text { Mid thoracic dural ectasia } \\
\text { secondary to Neurofibromatosis } \\
\text { Type } 1\end{array}$ & Not available \\
\hline 8 & $\begin{array}{l}\text { Moderate/severe, centred on the posterior } \\
\text { fossa Less prominent siderosis extends to } \\
\text { the cervical spine inferiorly and the } \\
\text { Sylvian fissures supratentorially }\end{array}$ & $\begin{array}{l}\text { Ataxia, myelopathy, reduced } \\
\text { hearing on right }\end{array}$ & $\begin{array}{l}\text { Left sided brachial } \\
\text { plexus injury }\end{array}$ & 14 years & $\begin{array}{l}\text { Ventral spinal dural defect } \\
\text { following brachial plexus injury }\end{array}$ & $\begin{array}{l}\text { Red cells } 570, \\
\text { trace } \\
\text { xanthochromia }\end{array}$ \\
\hline 9 & Mild, centred on the posterior fossa & No; Migraine and BPPV & $\begin{array}{l}\text { C7 neurofibroma } \\
\text { excised }\end{array}$ & Unknown & $\begin{array}{l}\text { C6/7 nerve root psuedomeningocele } \\
\text { following neurosurgery }\end{array}$ & Not available \\
\hline 10 & Moderate, centred on the posterior fossa & Hearing loss and ataxia & Brain tumour removed & Unknown & Intracranial dural defect following & Not available \\
\hline
\end{tabular}




\begin{tabular}{|c|c|c|c|c|c|c|}
\hline & $\begin{array}{l}\text { and extending up as far as the } \\
\text { interhemispheric fissure }\end{array}$ & & in childhood & & surgery & \\
\hline 11 & $\begin{array}{l}\text { Moderate, centred on the posterior fossa. } \\
\text { Siderosis extends to the cervical spine } \\
\text { inferiorly }\end{array}$ & No; Headaches only & No & Not applicable & $\begin{array}{l}\text { Spinal dural ectasia secondary to } \\
\text { Marfan's syndrome }\end{array}$ & Not available \\
\hline 13 & $\begin{array}{l}\text { Mild, centred on the posterior fossa and } \\
\text { cervical cord }\end{array}$ & $\begin{array}{l}\text { Lower limb myelopathy, leg } \\
\text { ataxia, reduced } \\
\text { proprioception to the knees. }\end{array}$ & $\begin{array}{l}\text { Teratoma excised from } \\
\text { thoracic cord }\end{array}$ & Unknown & $\begin{array}{l}\text { Posterior spinal dural defect } \\
\text { following neurosurgery }\end{array}$ & $\begin{array}{l}\text { Red cells } 650 \text {, } \\
\text { bilirubin } 0.007, \\
\text { oxyhemaglobin } \\
0.011 \text {, ferritin } 131 \\
\end{array}$ \\
\hline 14 & $\begin{array}{l}\text { Mild, centred on the posterior fossa and } \\
\text { cervical spine. Less prominent siderosis } \\
\text { extends up as far as the Sylvian fissures }\end{array}$ & Mild myelopathy & $\begin{array}{l}\text { Yes occipital } \\
\text { craniotomy for Chiari } \\
\text { Type } 1 \text { malformation }\end{array}$ & 27 years & $\begin{array}{l}\text { Sub occipital psuedomeningocele } \\
\text { following neurosurgery }\end{array}$ & Not available \\
\hline 15 & $\begin{array}{l}\text { Severe, centred on the posterior fossa. } \\
\text { Less prominent siderosis extends up as } \\
\text { far as the cerebral hemispheres }\end{array}$ & $\begin{array}{l}\text { No; headache and vomiting } \\
\text { only }\end{array}$ & No & Not applicable & $\begin{array}{l}\text { Ventral spinal collection without } \\
\text { obvious cause }\end{array}$ & Not available \\
\hline 16 & $\begin{array}{l}\text { Severe, centred on the posterior fossa. } \\
\text { Less prominent siderosis extends up as } \\
\text { far as the cerebral hemispheres including } \\
\text { the interhemispheric fissure. }\end{array}$ & $\begin{array}{l}\text { Ataxia, hearing loss and } \\
\text { myelopathy }\end{array}$ & No & Not applicable & $\begin{array}{l}\text { Ventral spinal collection without } \\
\text { obvious cause }\end{array}$ & Red cells 5600 \\
\hline 17 & $\begin{array}{l}\text { Moderate, centred on the posterior fossa. } \\
\text { Less prominent siderosis extends up as } \\
\text { far as the cerebral hemispheres including } \\
\text { the interhemispheric fissure }\end{array}$ & $\begin{array}{l}\text { Hearing loss, ataxia, anosmia, } \\
\text { myelopathy }\end{array}$ & Fall with spinal injury & 15 years & $\begin{array}{l}\text { Ventral spinal collection secondary } \\
\text { to spinal trauma }\end{array}$ & Not available \\
\hline 18 & Mild, centred on the cervical spine & $\begin{array}{l}\text { Myelopathy, hearing loss, } \\
\text { fatigue, bladder and sexual } \\
\text { dysfunction }\end{array}$ & $\begin{array}{l}\text { Occipital craniotomy for } \\
\text { Chiari Type } 1 \\
\text { malformation }\end{array}$ & 15 years & $\begin{array}{l}\text { Sub-occipital psuedomeningocele } \\
\text { following neurosurgery }\end{array}$ & Not available \\
\hline 19 & $\begin{array}{l}\text { Moderate/Severe, centred on the posterior } \\
\text { fossa. Less prominent siderosis extends } \\
\text { up as far as the cerebral hemispheres } \\
\text { including the interhemispheric fissure }\end{array}$ & $\begin{array}{l}\text { Hearing loss, ataxia, hearing } \\
\text { loss. }\end{array}$ & $\begin{array}{l}\text { Cerebellar astrocytoma } \\
\text { resected aged } 10 . \\
\text { Subsequent resection } \\
\text { and shunt }\end{array}$ & 17 years & $\begin{array}{l}\text { Sub-occipital psuedomeningocele } \\
\text { following neurosurgery }\end{array}$ & Not available \\
\hline 20 & $\begin{array}{l}\text { Moderate/severe, centred on the posterior } \\
\text { fossa and cervical spine. Less prominent } \\
\text { siderosis extends up as far as the cerebral } \\
\text { hemispheres including the } \\
\text { interhemispheric fissure. }\end{array}$ & $\begin{array}{l}\text { Hearing loss and vestibular } \\
\text { dysfunction. }\end{array}$ & $\begin{array}{l}\text { C8-T1 nerve root } \\
\text { avulsion }\end{array}$ & 39 years & $\begin{array}{l}\text { Nerve root avulsion and } \\
\text { psuedomeningocele following } \\
\text { spinal injury }\end{array}$ & Red cells 8961 \\
\hline 21 & $\begin{array}{l}\text { Moderate/severe, centred on the posterior } \\
\text { fossa. Less prominent siderosis extends } \\
\text { up as far as the cerebral hemispheres } \\
\text { including the interhemispheric fissure }\end{array}$ & $\begin{array}{l}\text { Hearing loss, ataxia, } \\
\text { myelopathy }\end{array}$ & Assault to spine & 15 years & $\begin{array}{l}\text { Ventral spinal collection and dural } \\
\text { defect at the cervico-thoracic } \\
\text { junction following spinal injury }\end{array}$ & $\begin{array}{l}\text { Ferritin } 114, \\
\text { bilirubin } 0.065, \\
\text { oxyhemoglobin } \\
0.055\end{array}$ \\
\hline
\end{tabular}




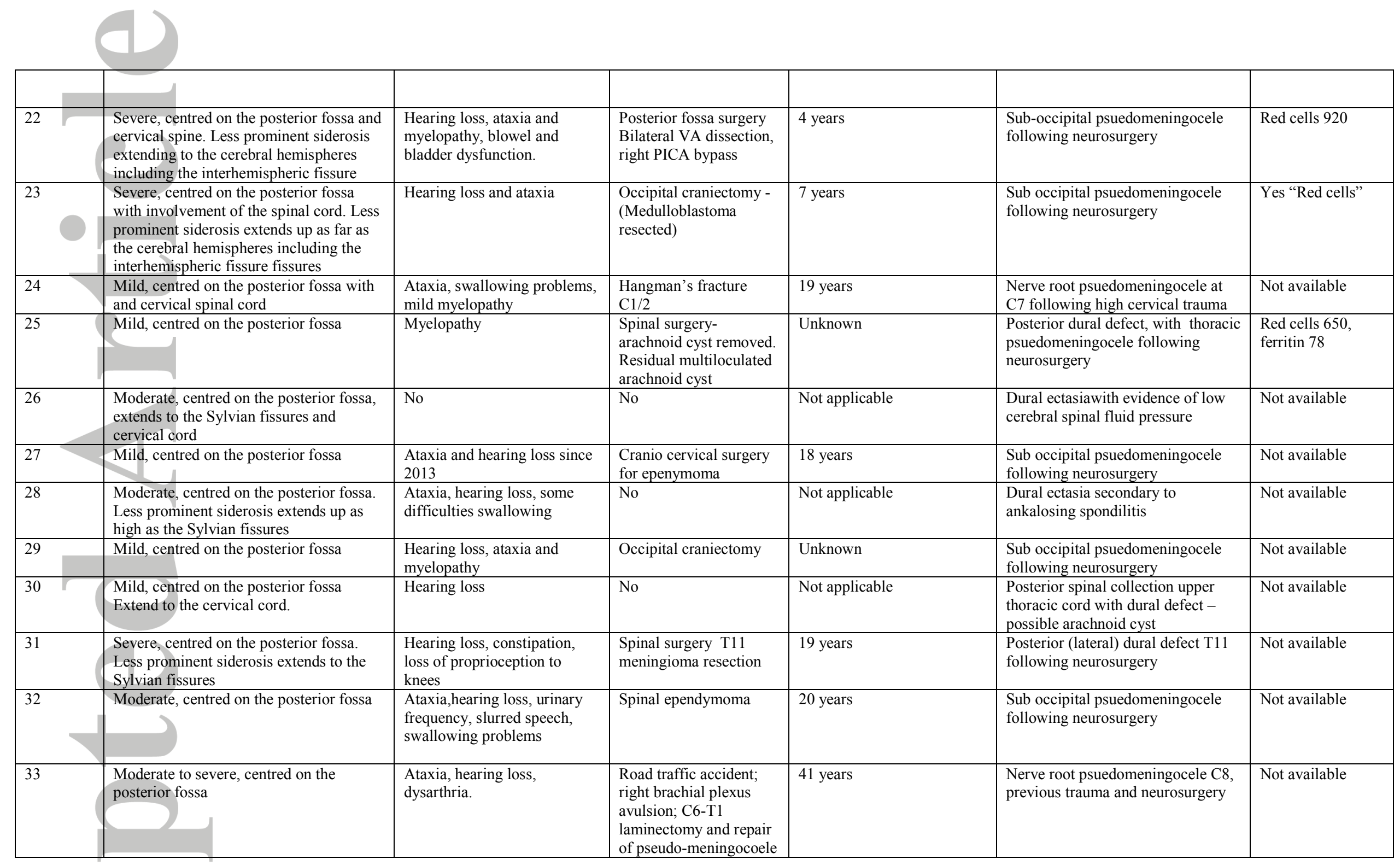

John Wiley \& Sons

This article is protected by copyright. All rights reserved. 


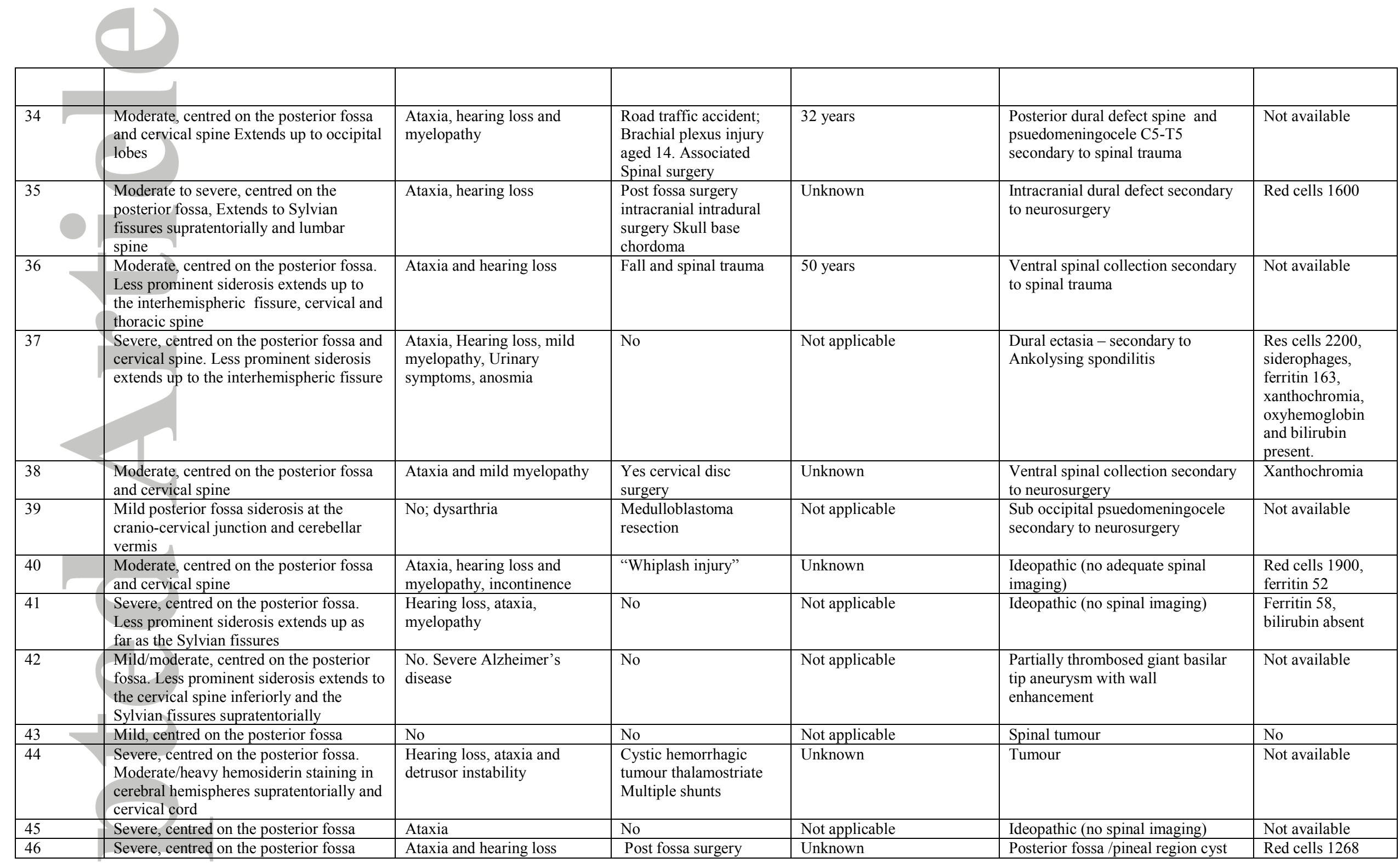

John Wiley \& Sons

This article is protected by copyright. All rights reserved. 


\begin{tabular}{|c|c|c|c|c|c|c|}
\hline & $\begin{array}{l}\text { extending up to the interhemispheric } \\
\text { fissures. }\end{array}$ & & $\begin{array}{l}\text { brainstem mass (Pineal } \\
\text { tumour) treated } \\
\text { endoscopically }\end{array}$ & & with blood products in it. & \\
\hline 47 & $\begin{array}{l}\text { Moderate, centred on the posterior fossa. } \\
\text { Less prominent siderosis extends up to } \\
\text { interhemispheric fissures }\end{array}$ & $\begin{array}{l}\text { Ataxia, incontinence and } \\
\text { cognitive decline }\end{array}$ & $\begin{array}{l}\text { Posterior fossa surgery } \\
\text { for a pineal tumour }\end{array}$ & Unknown & Pineal tumour & $\begin{array}{l}\text { Multiple CSF due } \\
\text { to ventriculitis, } \\
\text { Red cells } 85 \text { to } \\
>2000\end{array}$ \\
\hline 48 & Mild, centred on the posterior fossa & $\begin{array}{l}\text { Hearing loss and low pressure } \\
\text { syndrome }\end{array}$ & Cervical disc surgery & Unknown & $\begin{array}{l}\text { Ventral spinal collection secondary } \\
\text { to spinal surgery }\end{array}$ & Not available \\
\hline 49 & $\begin{array}{l}\text { Speckled siderosis, slight asymmetry } \\
\text { more prominent in right posterior fossa. }\end{array}$ & No & No & 9 months & Aneurysmal SAH & Not available \\
\hline 50 & $\begin{array}{l}\text { Symmetrical posterior fossa siderosis, } \\
\text { Large ICH (with surrounding siderosis, } \\
\text { more prominent than infratentorial } \\
\text { compartment) with ventricular spread. }\end{array}$ & No & No & Unknown & Lobar parenchymal ICH & Not available \\
\hline 51 & $\begin{array}{l}\text { Slender layer of siderosis centred around } \\
\text { the } 4^{\text {th }} \text { ventricle outlet. Parenchymal ICH } \\
\text { has more prominent siderosis than } \\
\text { infratentorial compartment }\end{array}$ & No & No & 2 years & Lobar parenchymal ICH & Not available \\
\hline 52 & $\begin{array}{l}\text { Heavy siderosis load in sylvian fissures } \\
\text { and cisterns of suprtentorial compartment } \\
\text { in addition to symmetrical infratentorial } \\
\text { siderosis in infratentorial structures. } \\
\text { Frank hematoma within the chiasmatic } \\
\text { cystern }\end{array}$ & No & No & 1 month & Aneurysmal SAH & Not available \\
\hline 53 & $\begin{array}{l}\text { Assymetric supratentorial hemosiderin } \\
\text { and slender subtle hemosiderin deposition } \\
\text { in post fossa and cranial cervical junction }\end{array}$ & No & $\begin{array}{c}\text { External ventricular } \\
\text { shunts required for SAH }\end{array}$ & 12 years & Aneurysmal SAH & Not available \\
\hline 54 & $\begin{array}{l}\text { Slender hemosiderin in posterior fossa } \\
\text { associated with heavy burden of } \\
\text { hemosiderin supratentorially }\end{array}$ & No & $\begin{array}{l}\text { Craniotomy and external } \\
\text { ventricular shunts }\end{array}$ & 13 years & $\begin{array}{c}\text { Previous surgery with associated } \\
\text { lobar ICH }\end{array}$ & Not available \\
\hline 55 & $\begin{array}{l}\text { Slender subtle hemosiderin in } \\
\text { infratentorial structures }\end{array}$ & No & No & 12 days & Aneurysmal SAH & Not available \\
\hline 56 & $\begin{array}{l}\text { Slender hemosiderin centred around } 4 \\
\text { ventricle outflow with large burden of } \\
\text { siderosis surrounding supratentorial } \\
\text { parenchymal ICH }\end{array}$ & No & No & 11 months & Deep ICH with IVH extension & Not available \\
\hline 57 & $\begin{array}{l}\text { Slender hemosiderin centred around } 4 \\
\text { ventricle outflow with large burden of } \\
\text { siderosis supratentorially and around } \\
\text { shunt tracts }\end{array}$ & No & $\begin{array}{l}\text { External ventricular } \\
\text { shunts }\end{array}$ & 6 months & Aneurysmal SAH & Not available \\
\hline
\end{tabular}

John Wiley \& Sons

This article is protected by copyright. All rights reserved. 


\begin{tabular}{|c|c|c|c|c|c|c|}
\hline & $\begin{array}{l}\text { ventricle outflow with large burden of } \\
\text { siderosis supratentorially and around } \\
\text { surgical site }\end{array}$ & & & & & \\
\hline 59 & $\begin{array}{l}\text { Slender hemosiderin centred around } 4 \\
\text { ventricle outflow with large burden of } \\
\text { siderosis supratentorially around ICH }\end{array}$ & No & No & 3 months & Intraventricular ICH & Not available \\
\hline 60 & $\begin{array}{l}\text { Prominent posterior fossa hemosiderin } \\
\text { and extensive hemosiderin surrounding } \\
\text { ICH }\end{array}$ & No & No & 7 months & Lobar parenchymal ICH & Not available \\
\hline 61 & $\begin{array}{l}\text { Slender hemosiderin centred around } 4 \\
\text { ventricle outflow with large burden of } \\
\text { siderosis from multiple supratentorial } \\
\text { ICHs }\end{array}$ & No & No & 2 years & Deep and lobar parenchymal ICH & Not available \\
\hline 62 & $\begin{array}{l}\text { Very thin slender posterior fossa } \\
\text { hemosderin }\end{array}$ & No & No & 8 months & Bilateral subdural hemorrhages & Not available \\
\hline 63 & $\begin{array}{l}\text { Slender hemosiderin centred around 4th } \\
\text { ventricle outflow with large burden of } \\
\text { siderosis supratentorially around ICH }\end{array}$ & No & No & 8 months & Lobar parenchymal ICH & Not available \\
\hline 64 & $\begin{array}{l}\text { Predominantly supratentorial siderosis } \\
\text { with multiple surgical interventions and } \\
\text { known SAH. Only very thin posterior } \\
\text { fossa siderosis }\end{array}$ & No & $\begin{array}{l}\text { Multiple external } \\
\text { ventricular shunts }\end{array}$ & 2 years 5 months & Aneurysmal SAH & Not available \\
\hline 65 & $\begin{array}{l}\text { Slender hemosiderin centred around } 4 \\
\text { ventricle outflow with large burden of } \\
\text { siderosis supratentorially around ICH }\end{array}$ & No & No & 15 days & Deep parenchymal ICH & Not available \\
\hline
\end{tabular}

Legend: ICH: intracerebral hemorrhage; SAH: subarachnoid hemorrhage; CSF cerebral spinal fluid; 